\title{
PENGARUH PENDIDIKAN KESEHATAN DENGAN MEDIA AUDIOVISUAL TESTIMONI ODHA DALAM MENURUNKAN STIGMA TERHADAP ODHA PADA MAHASISWA TINGKAT I AKPER PANTI KOSALA SURAKARTA
}

\author{
Wiwin Winarni ${ }^{1}$, Briantoko Lilih Waluyo Utomo²
}

\begin{abstract}
Giving stigma toward people who live with HIV/AIDS is not only can be found on common people lives in society but also among health workers. It is unbelievable if health workers whose education background is health will do the same thing toward people living with HIV/AIDS. Thus, it is necessary to have some strategies to prepare nursing students in order to reduce the discrimination which happen in health services facilities by health workers. Hence, the prevention efforts of HIV/AIDS cases in Indonesia can optimally be implemented.

The purpose of this study was to analyze the effect of health education through testimonial method in reducing stigma toward people living with HIV/AIDS on first year students in Panti Kosala Surakarta Nursing Academy.

This research used quasy experiment with pre post experimental design. The total population involved in this research were 106 first year students of Panti Kosala Nursing Academy. Total sampling was used as a sampling technique. Data was collected by using questionnaire. The data was then analyzed using Wilcoxon aided by SPSS serial 18.

There were three main results of this study : 1) The vast majority of first year students has high level of education about HIV/AIDS (98.11\%) and low level of stigma toward people living with HIV/AIDS (55.66\%) before had been given intervention. 2) The majority of first year students has high level of education about HIV/AIDS (99.05\%) and low level of stigma toward people living with HIV/AIDS (95.28\%) after had been given intervention. 3)The analysis Wilcoxon shows significancy number $p<0,000$. It can be concluded that health education through testimonial video has given significant effect in reducing stigma toward people living with HIV/AIDS on first year students in Panti Kosala Surakarta Nursing Academy.
\end{abstract}

Keywords: health education, audiovisual, stigma, people living with HIV/AIDS

\section{PENDAHULUAN}

Penelitian ini dilatarbelakangi oleh tingginya stigma terhadap ODHA baik pada masyarakat umum maupun tenaga kesehatan. Sangat disayangkan jika tenaga kesehatan dengan latar belakang pendidikan kesehatan juga melakukan diskriminasi terhadap ODHA. Oleh karena itu, diperlukan suatu upaya untuk mempersiapkan calon tenaga kesehatan sehingga tenaga kesehatan akan mampu merawat ODHA tanpa melakukan stigmatisasi dan diskriminasi di fasilitas pelayanan kesehatan. Dengan demikian, upaya pencegahan dan penanggulangan kasus HIV (Human Immunodeficiency Virus/AIDS (Acquired Immuno Deficiency Syndrome) di Indonesia dapat dilaksanakan dengan optimal.

Pada tahun 2015 diperkirakan terdapat 36,7 juta (34 juta-39,8 juta) orang hidup dengan HIV, meningkat sebanyak 3,4 juta dibandingkan tahun 2010. Sebanyak 2,1 juta diantaranya merupakan kasus baru HIV. Namun, dalam laporan yang sama terjadi penurunan kematian, WHO (World Health Organization) mencatat sejak AIDS ditemukan hingga akhir 2015 terdapat 34 juta orang meninggal dan di tahun 2015 
tercatat sebesar 1,1 juta orang meninggal terkait dengan AIDS, menurun dibandingkan tahun 2010 sebesar 1,5 juta kematian. Di Indonesia, HIV/AIDS pertama kali ditemukan di Provinsi Bali pada tahun 1987. Hingga saat ini HIV/AIDS sudah menyebar di 407 kota dari 507 kabupaten/kota (80\%) di seluruh provinsi Indonesia (Kemenkes RI, 2016).

Di Jawa Tengah sendiri pada tahun 2016 terdapat 747 kasus baru pada HIV dan 673 kasus baru pada AIDS, serta 78 orang meninggal akibat HIV/AIDS (Dinas Kesehatan Provinsi Jawa Tengah, 2016). Pada bulan Maret penanggulangan AIDS (KPA) Kota Solo mencatat jumlah pengidap HIV/AIDS yang terdeteksi di Solo dan sekitarnya awal tahun ini bertambah 112 orang. Perinciannya, 34 orang terdeteksi menderita HIV sedangkan 78 orang menderita AIDS. Tiga orang sudah meninggal dunia, salah satunya anak-anak serta ibunya juga yang terkena AIDS (Wakhidah, 2017).

Menurut Kamus Besar Bahasa Indonesia (KBBI) stigma adalah ciri negatif yang menempel pada pribadi seseorang karena pengaruh lingkungannya. Menurut Suranto, Siswaya, dan Riswanti (2007) stigmatisasi dan diskriminasi berlebihan seringkali terjadi di masyarakat, sehingga menjadi penghalang utama bagi upaya pencegahan infeksi HIV. Adanya stigma atau "cap buruk" menyebabkan penderita atau keluarganya menjadi enggan memeriksakan diri untuk memastikan atau mencegah untuk tidak menularkannya pada orang lain. ODHA (Orang Dengan HIVIAIDS) sering mendapatkan "cap buruk" tentang penyakitnya. Diantaranya ODHA disebut-sebut menderita "penyakit penyimpangan seksual atau gay", "penyakit pergaulan bebas", "penyakit kaum nakal", "penyakit orang kulit hitam", atau "penyakit orang asing". Akibat cap buruk tersebut penderita dikucilkan, dan bahkan hak asasi mereka ditindas dengan mendiskriminasikan penderita.

Status HIV positif yang disandang menyebabkan ODHA menjadi sangat sensitif dengan lingkungan di sekitarnya. Maharani (2017) dalam penelitian kualitatif dengan pendekatan fenomenologi yang dilakukan terhadap 3 ODHA dan 5 petugas kesehatan menunjukkan beberapa isu stigma dalam pelayanan kesehatan yang didengar ODHA sehingga membuat ODHA takut untuk melakukan pengobatan. Isu-isu tersebut antara lain isu bahwa jenazah ODHA dibungkus plastik dan dimasukkan dalam peti, penggunaan Alat Pelindung Diri (APD) yang berlebihan, anggapan bahwa ODHA adalah orang yang tidak benar, wanita yang positif HIV tidak boleh punya anak dan penolakan terhadap akses pelayanan kesehatan.

Sangat disayangkan ternyata stigma dan diskriminasi yang dilakukan oleh tenaga kesehatan memang dialami oleh ODHA di fasilitas kesehatan. Beberapa sikap diskriminasi dan stigmatisasi yang dilakukan oleh tenaga kesehatan dapat dijelaskan oleh Maharani (2014) dalam penelitian dengan judul Stigma dan Diskriminasi ODHA pada Pelayanan Kesehatan di Pekanbaru dengan menggunakan metode kualitiatif model fenomenologi. Hasil penelitian menyebutkan beberapa sikap diskriminasi yang diterima oleh ODHA dan keluarga atau temannya antara lain dilecehkan secara lisan dengan menyebut penyakit HIV dengan nada lantang, pemberian kode pada status pasien, penggunaan alat pelindung yang berlebihan, diisolasi dan mendapatkan tindakan medis tanpa informed consent. 
Penelitian yang dilakukan oleh Pratikno (2008) dengan judul Stigma dan Diskriminasi oleh Petugas Kesehatan terhadap ODHA di Kabupaten Bengkalis Riau terhadap 185 petugas kesehatan dipengaruhi oleh beberapa hal salah satunya adalah jenis tenaga kesehatan. Hasil penelitian menunjukkan bahwa tenaga medis /dokter memiliki stigma dan diskriminasi terhadap ODHA yang lebih rendah dibandingkan tenaga paramedis/perawat karena dokter memiliki persepsi yang lebih tinggi $(p=0,002)$.

Padahal seharusnya dalam memberikan asuhan keperawatan kepada pasien, perawat harus tulus dan ikhlas tanpa mengharapkan imbalan. Ketulusan ini diwujudkan dengan sikap perawat yang tidak membeda-bedakan dalam melayani klien. Semua klien harus dilayani perawat dengan baik (Asmadi, 2008). Hasil penelitian yang dilakukan oleh Waluyo, Nova dan Edison (2011), mengenai hubungan perilaku perawat terhadap orang dengan HIV/AIDS menunjukkan bahwa terdapat beberapa faktor yang mempengaruhi sikap perawat terhadap ODHA yaitu terkait faktor usia, jenis kelamin, tempat kerja, penghasilan, pengalaman kerja, latar belakang pendidikan, pelatihan HIV/AIDS dan persepsi kemampuan merawat ODHA.

Adanya stigma dan diskriminasi oleh petugas kesehatan terhadap ODHA akan menghambat upaya pencegahan dan penanggulangan HIV/AIDS. Oleh karena itu, sangat diperlukan upaya dini untuk menghilangkan stigma dan diskriminasi terhadap ODHA di kalangan tenaga kesehatan. Mempersiapkan tenaga kesehatan yang memahami HIV/AIDS dan perawatannya merupakan hal yang dapat diupayakan untuk mencapai tujuan tersebut. Tujuan ini dapat dicapai dengan meningkatkan pengetahuan mahasiswa mengenai HIV/AIDS melalui upaya pendidikan kesehatan. Widiyanto (2014), menjelaskan pendidikan kesehatan merupakan suatu upaya yang dilakukan untuk memberikan pengetahuan sebagai dasar perubahan perilaku yang dapat meningkatkan status kesehatan individu, keluarga, kelompok maupun masyarakat melalui aktivitas belajar.

Kholid (2012) menyebutkan kegiatan edukasi dapat dilakukn dengan menggunakan berbagai media seperti media visual, audio, multimedia dan benda. Oka (2017) menjelaskan bahwa media video memiliki beberapa kelebihan antara lain mampu memaparkan keadaan nyata dari suatu fenomena atau kejadian, sangat cocok untuk mengajarkan materi dalam ranah perilaku atau psikomotor dan lebih efektif serta cepat menyampaikan pesan dibandingkan media teks. Hal ini diperkuat dengan penelitian yang dilakukan oleh Prasetyo (2013) mengenai efektivitas metode ceramah dengan media interaktif dalam pembelajran bahasa Jepang di SMA Kasatrian 2 Semarang yang menunjukkan bahwa penggunaan metode ceramah dengan media interaktif terbukti efektif dalam pembelajaran bahasa Jepang $(\mathrm{t}$ tabel=2,46).

Berdasarkan hasil wawancara dengan beberapa mahasiswa keperawatan tingkat I Akademi Keperawatan Panti Kosala tentang HIV/AIDS didapatkan hasil 3 dari 10 mahasiswa masih belum mengerti benar tentang HIV/AIDS. Mahasiswa hanya mengetahui HIV/AIDS adalah penyakit yang menyerang kekebalan tubuh manusia dan menganggap bahwa jika mereka bertemu dengan ODHA mereka harus memakai masker dan menjaga jarak agar tidak tertular penyakit HIV/AIDS. 
Berdasarkan uraian latar belakang di atas dan belum adanya penelitian terkait stigma ODHA pada mahasiswa keperawatan, peneliti tertarik untuk melakukan penelitian tentang "Pengaruh Pendidikan Kesehatan dengan Media Audiovisual Testimoni ODHA dalam Menurunkan Stigma terhadap ODHA di Kalangan Mahasiswa Tingkat I Akademi Keperawatan Panti Kosala Surakarta".

\section{TUJUAN PENELITIAN}

Secara umum penelitian ini bertujuan untuk mengetahui pengaruh pendidikan kesehatan dengan media audiovisual testimoni ODHA dalam menurunkan stigma terhadap ODHA pada mahasiswa tingkat I Akademi Keperawatan Panti Kosala Surakarta. Secara khusus bertujuan untuk mengetahui gambaran stigma terhadap ODHA sebelum intervensi dan mengetahui gambaran stigma terhadap ODHA setelah intervensi pada mahasiswa tingkat I Akademi Keperawatan Panti Kosala Surakarta.

\section{METODE/DESAIN PENELITIAN}

Penelitian ini merupakan bentuk penelitian quasy experiment dengan pre post experimental design untuk mengetahui perbedaan stigma terhadap ODHA pada mahasiswa tingkat I sebelum dan setelah dilakukan intervensi. Pengumpulan data mengenai stigma terhadap ODHA dilakukan dengan menggunakan kuesioner. Tindakan intervensi yang diberikan berupa edukasi dengan menggunakan video testimoni ODHA. Analisa data pada penelitian ini menggunakan uji Wilcoxon dengan bantuan SPSS 18.

\section{POPULASI, SAMPEL DAN TEKNIK SAMPLING}

Populasi pada penelitian ini adalah seluruh mahasiswa tingkat I Akademi Keperawatan Panti Kosala Surakarta yang berjumlah 106 mahasiswa. Sampel yang digunakan adalah seluruh mahasiswa tingkat I. Teknik sampling yang peneliti gunakan adalah teknik sampling jenuh.

\section{HASIL PENELITIAN}

Berdasarkan penelitian yang telah dilakukan bulan Maret 2018 didapatkan data sebagai berikut :

Tabel 1.

Distribusi Frekuensi Tingkat

Pengetahuan tentang HIV/AIDS dan Stigma terhadap ODHA pada Mahasiswa Tingkat I (pre-intervensi)

\begin{tabular}{cccc}
\hline & Kategori & $\mathrm{f}$ & $\%$ \\
\hline Tingkat & Rendah & 2 & 1.88 \\
Pengetahuan & Tinggi & 104 & 98,11 \\
Stigma & Rendah & 59 & 55,66 \\
& Tinggi & 47 & 44,33 \\
\hline
\end{tabular}

Berdasarkan Tabel 1 didapatkan informasi bahwa sebelum diberikan edukasi audiovisual testimoni ODHA, sebagian besar mahasiswa tingkat I mempunyai tingkat pengetahuan yang tinggi mengenai HIV/AIDS sebanyak 104 mahasiswa $(98,11 \%)$ dan hanya 2 mahasiswa $(1,88 \%)$ yang mempunyai tingkat pengetahuan rendah. Sedangkan untuk variabel stigma terhadap ODHA mayoritas mahasiswa menunjukkan stigma yang rendah sebanyak 59 mahasiswa $(55,66 \%)$ dan sebanyak 47 mahasiswa $(44,33 \%)$ mempunyai stigma yang tinggi terhadap ODHA. 
Tabel 2.

Distribusi Frekuensi Tingkat

Pengetahuan tentang HIV/AIDS dan

Stigma terhadap ODHA pada

Mahasiswa Tingkat I

(Post-Intervensi)

\begin{tabular}{cccc}
\hline & Kategori & $\mathrm{f}$ & $\%$ \\
\hline Tingkat & Rendah & 1 & 0,94 \\
Pengetahuan & Tinggi & 105 & 99,05 \\
Stigma & Rendah & 101 & 95,28 \\
& Tinggi & 5 & 4,71 \\
\hline
\end{tabular}

Tabel 2 menunjukkan bahwa setelah dilakukan intervensi berupa pemberian edukasi melalui audiovisual testimoni ODHA didapatkan bahwa sebagian besar mahasiswa tingkat I mempunyai tingkat pengetahuan yang tinggi mengenai HIV/AIDS sebanyak 105 mahasiswa $(99,05 \%)$ dan hanya 1 mahasiswa yang masuk dalam kategori tingkat pengetahuan rendah $(0,94 \%)$. Sedangkan untuk variabel stigma terhadap ODHA didapatkan hasil sebagian besar mahasiswa menunjukkan stigma yang rendah terhadap ODHA sebanyak 101 mahasiswa $(95,28 \%)$ dan hanya 5 mahasiswa (4.71\%) yang mempunyai stigma tinggi terhadap ODHA.

Tabel 3.

Distribusi Frekuensi Pengalaman Interaksi dengan ODHA

\begin{tabular}{|c|c|c|c|c|}
\hline \multicolumn{2}{|c|}{$\begin{array}{c}\text { Pengalaman } \\
\text { Interaksi }\end{array}$} & $f$ & \multicolumn{2}{|c|}{$\%$} \\
\hline \multicolumn{2}{|c|}{$\begin{array}{c}\text { Pernah } \\
\text { Tidak Pernah }\end{array}$} & $\begin{array}{c}5 \\
101\end{array}$ & & \\
\hline & $\mathrm{n}$ & $\begin{array}{r}\mathrm{N} \\
(\mathrm{mi} \\
\mathrm{mal}\end{array}$ & & $p$ \\
\hline $\begin{array}{l}\text { Sebelum } \\
\text { intervensi }\end{array}$ & 106 & & & 0,029 \\
\hline $\begin{array}{l}\text { Sesudah } \\
\text { intervensi }\end{array}$ & 106 & 16 & & \\
\hline Jumlah & & 106 & & \\
\hline
\end{tabular}

Berdasarkan Tabel 3 diperoleh informasi bahwa sebagian besar mahasiswa belum pernah
mempunyai
berinteraksi dengan ODHA sebanyak 101 mahasiswa (95.28\%) dan 5 mahasiswa (4.72\%) mempunyai pengalaman berinteraksi dengan ODHA.

Tabel 4.

Analisa Uji Wilcoxon

Tingkat Pengetahuan HIV/AIDS

Berdasarkan analisa uji Wilcoxon pada Tabel 4 diperoleh angka significancy 0,029. Karena nilai $p<0,05$, dapat disimpulkan bahwa terdapat perbedaan bermakna antara tingkat pengetahuan HIV/AIDS sebelum dan sesudah diberikan edukasi audiovisual testimoni ODHA pada mahasiswa tingkat I.

Tabel 5

Analisa Uji Wilcoxon Stigma

\begin{tabular}{|c|c|c|c|}
\hline & $\mathrm{N}$ & $\begin{array}{c}\text { Median } \\
\text { (minimum- } \\
\text { maksimum) }\end{array}$ & $p$ \\
\hline $\begin{array}{l}\text { Sebelum } \\
\text { intervensi }\end{array}$ & 106 & $6(0-10)$ & 0.000 \\
\hline $\begin{array}{l}\text { Sesudah } \\
\text { intervensi }\end{array}$ & 106 & $9(3-10)$ & \\
\hline
\end{tabular}

Berdasarkan analisa uji Wilcoxon pada Tabel 5 diperoleh angka significancy 0,000 . Karena nilai $\mathrm{p}<0,05$, dapat disimpulkan bahwa terdapat perbedaan bermakna stigma terhadap ODHA sebelum dan sesudah perlakuan pada mahasiswa tingkat I.

\section{PEMBAHASAN}

Berdasarkan Tabel 1 didapatkan bahwa sebelum diberikan edukasi audiovisual testimoni ODHA, sebagian besar mahasiswa tingkat I mempunyai tingkat pengetahuan yang tinggi mengenai HIV/AIDS sebanyak 104 mahasiswa $(98,11 \%)$ dan hanya 2 mahasiswa $(1,88 \%)$ yang mempunyai tingkat pengetahuan rendah. Sedangkan untuk variabel stigma terhadap ODHA mayoritas mahasiswa 
menunjukkan stigma yang rendah sebanyak 59 mahasiswa (55,66\%) dan sebanyak 49 mahasiswa $(44,33 \%)$ mempunyai stigma yang tinggi terhadap ODHA.

Menurut Ardhiyanti, Lusiana, dan Megasari (2015), stigma adalah bentuk prasangka (prejudice) yang mendiskreditkan atau menolak seseorang atau kelompok karena mereka dianggap berbeda dengan diri kita atau kebanyakan orang. Stigma berhubungan dengan kekuasaan dan dominasi di masyarakat. Pada puncaknya, stigma akan menciptakan ketidaksetaraan sosial. Stigma berurat akar di dalam struktur masyarakat, dan juga dalam normanorma dan nilai-nilai yang mengatur kehidupan sehari-hari, ini menyebabkan beberapa kelompok menjadi kurang dihargai dan merasa malu, sedangkan kelompok lainnya merasa superior.

Rohan et al. (2017) menjelaskan bahwa diskriminasi terhadap ODHA dapat terjadi karena kurangnya informasi yang benar mengenai HIV/AIDS khususnya mengenai bagaimana cara penularan HIV/AIDS. Hal ini mencakup hal-hal apa saja yang dapat menularkan dan apa yang tidak dapat menularkan. Shaluhiyah, Musthofa dan Widjanarko (2015) menyebutkan kesalahpahaman atau kurangnya pengetahuan masyarakat tentang HIV/AIDS seringkali berdampak pada ketakutan masyarakat terhadap ODHA sehingga memunculkan penolakan terhadap ODHA.

Jika dikaitkan dengan hasil penelitian ini maka ada korelasi antara tingkat pengetahuan dan stigma terhadap ODHA. Sebagian besar mahasiswa tingkat I mempunyai tingkat pengetahuan yang tinggi mengenai HIV/AIDS sebanyak 104 mahasiswa $(98,11 \%)$ dan sebanyak 59 mahasiswa $(55,66 \%)$ memiliki stigma yang rendah terhadap ODHA. Hasil analisa tersebut menguatkan hasil penelitian yang dilakukan oleh Maharani (2017) mengenai faktorfaktor yang berhubungan dengan stigma terhadap ODHA. Hasil penelitian menunjukkan bahwa tingkat pengetahuan dan interaksi dengan ODHA di kalangan remaja SMA mempengaruhi stigmatisasi terhadap ODHA. Tingkat pengetahuan yang kurang dan interaksi dengan ODHA yang minim akan menyebabkan stigma yang tinggi terhadap ODHA. Sebaliknya, tingkat pengetahuan yang tinggi dan interaksi dengan ODHA yang intensif akan mengurangi persepsi negatif mengenai ODHA.

Berdasarkan Tabel 2, setelah dilakukan intervensi berupa pemberian edukasi melalui audiovisual testimoni ODHA kepada responden didapatkan bahwa sebagian besar mahasiswa tingkat I mempunyai tingkat pengetahuan yang tinggi mengenai HIV/AIDS sebanyak 105 mahasiswa (99.05\%) dan hanya 1 mahasiswa yang masuk dalam kategori tingkat pengetahuan rendah $(0,94 \%)$. Sedangkan untuk variabel stigma terhadap ODHA didapatkan hasil sebagian besar mahasiswa menunjukkan stigma yang rendah terhadap ODHA sebanyak 101 mahasiswa $(95,28 \%)$ dan hanya 5 mahasiswa $(4,71 \%) \quad$ yang mempunyai stigma tinggi terhadap ODHA.

Dari data di atas, didapatkan adanya peningkatan tingkat pengetahuan tentang HIV/AIDS pada responden yang dibuktikan dengan jumlah mahasiswa dengan tingkat pengetahuan tinggi sebanyak $98,11 \%$ menjadi $99,05 \%$ dan penurunan jumlah mahasiswa dengan stigma yang tinggi terhadap ODHA dari $44,33 \%$ menjadi $4,71 \%$. Dapat disimpulkan bahwa tindakan edukasi yang diberikan kepada responden dapat meningkatkan 
pengetahuan tentang HIV/AIDS dan menurunkan stigma terhadap ODHA.

Berdasarkan analisa uji Wilcoxon pada tabel 4 diperoleh angka significancy 0,029. Karena nilai $\mathrm{p}<0,05$, dapat disimpulkan bahwa terdapat perbedaan bermakna antara tingkat pengetahuan HIV/AIDS sebelum dan sesudah diberikan edukasi audiovisual testimoni ODHA pada mahasiswa tingkat I. Berdasarkan analisa uji Wilcoxon pada tabel 5, diperoleh angka significancy 0,000 . Karena nilai $\mathrm{p}<0,05$, dapat disimpulkan bahwa terdapat perbedaan bermakna stigma terhadap ODHA sebelum dan sesudah perlakuan pada mahasiswa tingkat I.

Menurut Widiyanto (2014), pendidikan kesehatan merupakan upaya yang dilakukan untuk memberikan pengetahuan sebagai dasar perubahan perilaku yang dapat meningkatkan status kesehatan individu, keluarga, kelompok maupun masyarakat melalui aktivitas belajar. Kegiatan pendidikan kesehatan diharapkan dapat membantu tercapainya program pengobatan, rehabilitasi, pencegahan penyakit dan peningkatan kesehatan. Proses transfer informasi dapat berjalan dengan baik jika dibantu dengan menggunakan media pembelajaran. Sebagaimana dijelaskan oleh Kholid (2012) bahwa media pembelajaran dapat mengatasi keterbatasan pengalaman yang dimiliki oleh audience. Media audiovisual memungkinkan audience mendapatkan informasi dalam bentuk visual dan dapat didengarkan melalui indra pendengaran (Kholid, 2012). Oka (2017) menyebutkan bahwa kombinasi video dan audio dapat lebih efektif dan lebih cepat menyampaikan pesan dibandingkan media teks.
Hasil penelitian ini sejalan dengan penelitian yang dilakukan oleh Fresia (2016) mengenai Efektifitas Pemberian Edukasi Berbasis Audiovisual dan Tutorial tetang Antirertoviral (ARV) terhadap Kepatuhan Pengobatan Pada Pasien HIV/AIDS di Klinik Teratai Rumah Sakit Hasan Sadikin Bandung. Penelitian quasy experiment tersebut menunjukkan bahwa terdapat perbedaan yang signifikan rata-rata kepatuhan pada masing-masing kelompok intervensi edukasi. Hasil penelitian didapatkan bahwa kombinasi edukasi berbasis audiovisual dan tutorial memberikan hasil yang paling baik.

Dari Tabel 3 dapat diketahui bahwa sebagian besar mahasiswa belum pernah mempunyai pengalaman berinteraksi dengan ODHA sebanyak 101 mahasiswa $(95,37 \%)$ dan 5 mahasiswa $(4,63 \%)$ mempunyai pengalaman berinteraksi dengan ODHA. Dengan melihat video testimoni ODHA, responden mendapatkan kesempatan untuk dapat melihat dan mendengarkan secara langsung stigma dan diskriminasi oleh masyarakat yang diterima oleh ODHA. Video tersebut dapat menjadi media bagi responden untuk berinteraksi secara tidak langsung dengan ODHA.

Pada penelitian ini, video yang dipakai sebagai media edukasi diambil dari tayangan acara Mata Najwa dengan tema "Hidup Dalam Stigma". Video tersebut terdiri dari tiga sesi wawancara yang berbeda terhadap ODHA. Sesi pertama berisi wawancara dengan seorang ibu rumah tangga yang tertular virus HIV dari suaminya. Sesi kedua berisi wawancara terhadap ODHA yang mendapatkan stigma dan diskriminasi dari tempat bekerja dan lingkungan tempat tinggal. Sesi ketiga berisi wawancara terhadap pasangan ODHA dimana suami 
dengan status negatif menikahi wanita dengan status positif HIV. Sebagaimana dijelaskan oleh Kholid (2012), bahwa media pembelajaran dapat mengatasi keterbatasan pengalaman yang dimiliki oleh audience. Oka (2017) menyebutkan bahwa media video mempunyai kelebihan dibandingkan media yang lain yaitu mampu memaparkan keadaan nyata dari suatu proses fenomena atau kejadian. Dengan video testimoni ODHA pada penelitian ini, mahasiswa mampu mendapatkan keadaan nyata yang terjadi di masyarakat mengenai stigma terhadap ODHA. Sehingga dapat disimpulkan bahwa edukasi dengan menggunakan video testimoni ODHA terbukti dapat meningkatkan pengetahuan mengenai HIV/AIDS sehingga mampu secara efektif menurunkan stigma terhadap ODHA.

\section{KESIMPULAN}

1. Sebelum dilakukan intervensi sebagian besar responden mempunyai tingkat pengetahuan yang tinggi tentang HIV/AIDS (98.11\%) dan stigma yang rendah terhadap ODHA (55.66\%).

2. Setelah dilakukan intervensi sebagian besar responden mempunyai tingkat pengetahuan yang tinggi tentang HIV/AIDS (99.05\%) dan stigma yang rendah terhadap ODHA (95.28\%).

3. Berdasarkan analisa uji Wilcoxon variabel stigma terhadap ODHA sebelum dan sesudah intervensi dapat diperoleh angka significancy 0,000 . Karena nilai $p<0,05$, dapat disimpulkan bahwa terdapat perbedaan bermakna stigma terhadap ODHA sebelum dan sesudah perlakuan.

4. Berdasarkan analisa uji Wilcoxon variabel tingkat pengetahuan tentang HIV/AIDS diperoleh angka significancy 0,029 . Karena nilai $p<0,05$, dapat disimpulkan bahwa terdapat perbedaan bermakna antara tingkat pengetahuan HIV/AIDS sebelum dan sesudah diberikan edukasi audiovisual testimoni ODHA pada mahasiswa tingkat I.

\section{SARAN}

1. Bagi tenaga kesehatan disarankan untuk menggunakan media audiovisual testimoni ODHA saat menyampaikan pendidikan kesehatan khususnya mengenai stigma terhadap ODHA.

2. Bagi Peneliti selanjutnya disarankan untuk melakukan penelitian mengenai metode dan media pendidikan kesehatan lain yang dapat digunakan untuk meningkatkan keberhasilan upaya pendidikan kesehatan khususnya mengenai HIV/AIDS.

\section{DAFTAR PUSTAKA}

Ardhiyanti, Yulrina, Novita Lusiana, dan Kiki Megasari. 2015. Bahan Ajar AIDS pada Asuhan Kebidanan. Dilihat pada tanggal 28 Oktober 2017.

https://books.google.co.id/bo oks?id=ej.

Asmadi. 2008. Teknik Prosedural Perawatan Konsep dan Aplikasi Kebutuhan Dasar Klien. Dilihat pada tanggal 7 Oktober 2017. https://books.google.co.id/bo oks?id=IJ3P1..

Dinas Kesehatan Provinsi Jawa Tengah. 2016. Buku Saku Kesehatan Triwulan 2 Tahun2016.http://www.dinke sjatengprov.go.id/v2015/dok umen/bukusaku tw2 2016/ mobile/index.html\#p=1. Diakses pada tanggal 13 Oktober 2017. 
Fresia, Sinta. 2016. Efektivitas Pemberian Edukasi Berbasis Audiovisual dan Tutorial Tentang Antiretroviral (ART) terhadap Kepatuhan Pengobatan Pada Pasien HIV/AIDS di Klinik Teratai Rumah Sakit Hasan Sadikin Bandung. The Indonesian Journal of Infectious Diseases. Vol 3. No 2. Bandung. Diakses pada tanggal 13 Desember 2018.

Kamus Besar Bahasa Indonesia. https://kbbi.kemdikbud.go.id/ entri/Stigma. dilihat pada tanggal 7 Oktober 2017.

Kementrian Kesehatan Republik Indonesia. 2016. Situasi Penyakit HIV/AIDS di Indonesia.http://www.pusdati n.kemkes.go.id/article/view/. Diakses pada tanggal 5 Oktober 2017.

Kholid, Ahmad. 2012. Promosi Kesehatan. PT Rajagraf Indo Persada, Depok.

Maharani, Febrianti. 2017. Faktorfaktor yang Berhubuungan Dengan Stigma Terhadap Orang Dengan HIV Dan AIDS (ODHA). Jurnal Endurance Vol 2 No 2. Pekanbaru

Maharani, Riri. 2014. Stigma dan Diskriminasi Orang Dengan HIV/AIDS (ODHA) Pada Pelayanan Kesehatan di Kota Pekanbaru. Jurnal Kesehatan Komunitas. Vol 2 , No 5. Pekanbaru. Diunduh 3 Oktober 2018.

Oka, Putu Arya. 2017. Media dan Multimedia Pembelajaran. CV Budi Utama, Yogyakarta.

Praktikno, Heri. 2008. Stigma dan Diskriminasi Oleh Petugas Kesehatan Terhadap ODHA (Orang Dengan HIV-AIDS) di Kabupaten Bengkalis Propinsi Riau. Tesis. http://digilib.ugm.ac.id. Diakses 8 Oktober 2018.
Prasetyo, Teguh. 2013. Efektivitas Metode Ceramah Plus dengan Media Interaktif dalam Pembelajaran Bahasa Jepang di SMA Kasatrian 2 Semarang. Skripsi. http://lib.unnes.ac.id/18458/. Diakses 8 Oktober 2018.

Rohan, Hasdianah Hasan, et al. 2017. Buku Kesehatan Reproduksi Pengenalan Penyakit Menular Reproduksi dan Pencegahan. Intimedia, Malang.

Shaluhiyah, Z., S. B. Musthofa dan B. Wdjanarko. 2015. Stigma Masyarakat Terhadap Orang Dengan HIV/AIDS. Kesmas National Public Journal. Vol $9 \quad$ No 4. http://journal.fkm.ui.ac.id/kes mas/article/view/740.

Diakses tanggal 9 Oktober 2018.

Wakhidah, Hijriyah Al. 2017. Pengidap HIVIAIDS di Solo Tahun Ini Bertambah 112 orang.

http://m.solopos.com/.Diakse $\mathrm{s}$ pada tanggal 6 Oktober 2017.

Waluyo, Agung, Prima Agustia Nova, dan Chiyar Edison. 2011. "Perilaku Perawat terhadap Orang dengan HIV/AIDS di Rumah Sakit dan Puskemas". Jurnal Keperawatan Indonesia. Volume 14, No. 2. Depok. Diunduh pada tanggal 7 Oktober 2017.

Widiyanto, Agus Mika. 2014. Pendidikan Kesehatan. PT Alex Media Komputindo, Jakarta.

${ }^{1}$ Dosen Akper Panti Kosala

Surakarta

${ }^{2}$ Mahasiswa Akper Panti Kosala

Surakarta 
•KOSntด : Jurnal Ilmu Kesehatan״・ Vol. 7 No. 2 November 2019 